\title{
Retraction Note: Corporate Social Responsibility in Purchasing and Supply Chain
}

\author{
Mohammad Asif Salam
}

Published online: 5 January 2013

(C) Springer Science+Business Media Dordrecht 2013

\section{Retraction to: J Bus Ethics (2009) 85:355-370 DOI 10.1007/s10551-008-9733-0}

The Editors and publisher regret to report that the paper published by Mohammad Asif Salam as "Corporate social responsibility in purchasing and supply chain" in the Journal of Business Ethics (2009), 85:355-370 is nearly identical to that published earlier by Mohammad Asif Salam as "Social responsibility in purchasing: the case of
Thailand" in the International Journal of Procurement Management (2007), 1:97-116. This is a serious violation of publication ethics which according to the Springer Policy on Publishing Integrity warrants a retraction notice to be published in the journal and a ban from publishing "in any of the journal's publications for an initial period of 5 years".

Alex C. Michalos

The online version of the original article can be found under doi:10.1007/s10551-008-9733-0.

M. A. Salam ( $\square)$

Marketing and Supply Chain Management,

School of Management, Assumption University, Box 640,

ABAC, 24 Ramkhamhaeng Road, Bangkok 10240, Thailand

e-mail: mbamas@yahoo.com 